JOURNAL OF SECURITY AND SUSTAINABILITY ISSUES

ISSN 2029-7017 print/ISSN 2029-7025 online

2020 September Volume 10 Number 1

https://doi.org/10.9770/jssi.2020.10.1(7)

Scopus

\title{
ECONOMIC INSTRUMENTS TO SUPPORT THE POPULATION \\ AND ELIMINATE THE CONSEQUENCES OF APPLYING EMERGENCY MEASURES TO PROTECT THE COUNTRY'S SECURITY
}

\author{
Gulnar Shaimardanovna Kaliakparova ${ }^{1}$, Yelena Evgenevna Gridneva ${ }^{2}$, Sara Sarsebekovna Assanova ${ }^{3}$, \\ Kulyash Shaymoldenovna Syzdykova ${ }^{4}$, Sandugash Babagalikyzy Sauranbay ${ }^{5}$ \\ 1,2,3,4 Kainar University, Almaty, Kazakhstan \\ ${ }^{5}$ Almaty Management University, Almaty, Kazakhstan
}

Received 15 February 2020; accepted 10 July 2020; published 30 September 2020

\begin{abstract}
The constant presence of natural and anthropogenic hazards in the social development processes suggests the need to take them into account when predicting its development. Today, due to the spread of the COVID-19 pandemic, various economic instruments have been implemented in most countries to support the population and stabilize the economy after taking emergency measures to prevent the incidence of coronavirus infection. Based on the expert survey, the authors have determined the socio-economic and macroeconomic impact of the COVID-19 pandemic, different approaches to respond in various life spheres of the population, as well as measures undertaken by different countries to support the population and national economy in the context of the COVID-19 pandemic.
\end{abstract}

Keywords: natural and anthropogenic security; pandemic; COVID-19; Coronavirus infection; virtualization; fundamentals of computer science; operating systems; virtualization tools

Reference to this paper should be made as follows: Kaliakparova, G.S., Gridneva, Y.E., Assanova, S.S., Syzdykova, K.S., Sauranbay, S.B. 2020. Economic instruments to support the population and eliminate the consequences of applying emergency measures to protect the country's security. Journal of Security and Sustainability Issues, 10(1), 91-100. https://doi.org/10.9770/jssi.2020.10.1(7)

JEL Codes: I1, I2, I3

\section{Introduction}

A generally recognized trend of civilizational development at the present stage is a significant increase in socioeconomic losses from various hazards, which are caused by natural and anthropogenic processes (Tokhayeva, et al., 2020; Golubev, et al., 2020; Kulikov, \& Minakov, 2019; Plèta et al., 2020).

The interdependence of natural and anthropogenic security factors is confirmed today at a fundamental level (Eakin \& Luers, 2006). Besides, in recent decades, many countries have faced the effect of the synergetic strengthening of adverse factors of various natures. For example, adverse weather conditions or natural disasters lead to serious economic losses that cause large social expenditures. This leads to the fact that society becomes even more unstable regarding accidents and catastrophes due to the triggered dominoes effect (Myers, \& Patz, 2009).

The urgency of improving approaches to solving natural and anthropogenic safety (NAS) problems is caused by the unresolved conceptual, theoretical, and methodological aspects of analysis, integrated assessment, and response to natural and anthropogenic hazards of complicated systems (Thomalla, et al., 2006). At that, there is a contradiction between the need to analyze the state of various systems to prevent the occurrence of threatening situations caused by the interaction of natural and anthropogenic factors, on the one hand, and the lack of adequate scientific and methodological support for responding to their occurrence, on the other hand (Katan- 
aeva, et al., 2020; Melnikov, et al., 2019).

The NAS related problems have received considerable attention in scientific research. Scientists have developed theoretical and methodological foundations for qualitative and quantitative assessment of the NAS level, and methods to minimize socio-economic losses when implementing dangerous situations. The analysis and management problems concerning risks of natural and anthropogenic origin are considered in scientific works of leading scientists (Abdikerova, \& Omarova, 2016; Western, 2016; Bostrom, 2019; Baum, 2015; Avin, et al., 2018).

Nevertheless, it should be noted that the issues of ensuring the security of social development, countering real threats to development, supporting the population, and eliminating the consequences of the applied emergency measures, taking into account the comprehensive solution of security problems, remain insufficiently studied. Analysis of research results (Smith, \& Ezzati, 2005; Cascio, 2019; Burkaltseva et al., 2019) shows the need to develop theoretical and methodological principles that would ensure systematic support of the population and eliminate the consequences of emergency measures to ensure NAS.

Without taking into account a human factor, the security problem of any system loses its meaning. The security problem concerns primarily the security of a human (Aitkazina, et al., 2019; Bulkhairova, et al., 2019; Lipinsky, Makareiko, Musatkina, 2019). However, the key role in ensuring security is played by professionalism, ethical and moral foundations, and the values of those people who face dangers. Therefore, the fact that the human is both the main object and subject of research on NAS problems should be defining principle (Axworthy, 2001).

The Organization for Economic Cooperation and Development (OECD) identifies four global shocks that are destabilizing the development of the contemporary world, which will directly affect the health indicators of the global population. These are 1) viral epidemics, 2) cyber threats, 3) financial crises, and 4) socio-economic unrest (OECD, 2011). The interrelation of such global shocks quite clearly characterizes the integrality of crises that affect the stability indicators of the population's life activity. Indeed, crisis threats in one part of the world always predetermine the trends of crisis phenomena, which can probably affect the development of the entire world.

Most experts pay special attention to the danger of large-scale epidemics, the total expansion of the danger of large-scale epidemiological thresholds in the context of asociality and mobility of the global community. In this regard, the American $\mathrm{CDC}^{1}$ service, when monitoring epidemiological thresholds, predicts the emergence of new viruses and microbes in the world, reinforced by vaccines and antibiotics, which will mutate especially dangerously over the next decades covering a large part of the planet (Bambery, et al., 2018).

The danger of large-scale epidemics has now become particularly urgent due to the spread of COVID-19 coronavirus infection. Consequences of this global issue is alredy widely discussed in scientific literature (Razif et al., 2020; Akeel, Khoj, 2020; Oliński, Szamrowski, 2020; Yuesti et al., 2020, Besenyő, Kármán, 2020).

The first case of infection was detected in Kazakhstan on March 13, 2020. As of April 17, the number of confirmed incidences has reached 1,480, among which 17 were fatal. It should be noted that the confirmed cases are related to the number of laboratory tests performed, so there is concern that the actual number of cases is higher.

Since the number of cases of coronavirus infection increases daily, there is growing concern about the ability of the health system to cope with an unprecedented load. Although it is difficult to predict the exact number of people who will be affected by COVID-19 at this stage; it is estimated that up to 50\% of the population may be infected. Of these, up to $20 \%$ of cases may be severe, while $5 \%$ may be critical (OECD, 2020). For many people, the infectious disease may be asymptomatic or with undetected symptoms, similar to those of seasonal flu. While much remains unknown about coronavirus infection, there is growing evidence that the greatest risks are for older people. A significant proportion of older people (over 60 years of age) amounting to 13.2\% further increases vulnerability. Almost all of them have at least one chronic disease, which makes them particularly vulnerable to COVID-19 coronavirus infection (OECD, 2020).

1 Centers for Disease Control and Prevention 
In connection with the spread of coronavirus infection, state authorities of the Republic of Kazakhstan (RK) have declared a state of emergency, i.e. the operation of large malls is limited; the activities of the shopping and recreation centers, as well as cinemas and other objects with mass congestion of people, are suspended; largescale sanitary and anti-epidemic activities are being carried out; holding of various public and family events, as well as memorable events are prohibited; entrance in the territory of the RK and departure from its territory are restricted for all types of transport.

Measures are being taken to support the population and eliminate the consequences of applying emergency measures. Thus, to provide state support to small and medium-sized enterprises (SMEs), the following measures have been implemented:

- suspending payments of principal and interest on loans of all SMEs which suffered due to the complex situation that has been developed in the RK's market;

- providing preferential loans to the working capital of SMEs for KZT 600 bln for one year at the rate of 8\%;

- granting SMEs a deferred payment of all types of taxes and other mandatory payments for three months, without accrual of fines and penalties;

- suspending for three months of accrual of lease payments for SMEs from the use of real estate owned by local executive bodies and quasi-public sector entities (Eurasian Economic Commission, 2020).

The issue of removing import duties on socially important food products and critical imports to saturate the domestic market is under consideration. A green corridor has been established for socially important products at the customs borders. These measures are taken to ensure the uninterrupted provision of essential goods to the population. The main importers of socially important goods are exempted from applying forms of customs control during custom procedures.

Along with this, the need for reducing temporarily VAT on agricultural products and food products, setting duties on critically important imports to zero, is being considered.

At the initiative of the President of the RK, a specially established Republican Fund accumulates funds of those who want to provide financial help to the country. As of 21.03.2020, the Fund's capital amounted to USD 41 mln of contributions from Kazakhstan businesses. The Fund's finances are used to purchase medical products; personal protective gear; artificial lung ventilation apparatuses; as well as food and necessities for socially vulnerable segments of the population. Thus, as of 25.03.2020, the total package of anti-crisis measures in Kazakhstan, excluding tax preferences and support at the local level, amounted approximately to USD 10 bln (Kurmasheva, 2020).

The purpose of the present article is to analyze the economic tools to support the population and eliminate the consequences of applying emergency measures to protect the country's security.

Research hypothesis is as follows: the use of economic tools to support the population and eliminate the consequences of applying emergency measures to protect the country's security will ease the socio-economic situation of the population and minimize the impact of restrictive measures on the country's economic development. Based on the research results, it can be concluded that the goal set in the study was achieved.

\section{Methods}

A set of theoretical and empirical methods was used in the research. Theoretical methods, such as the analysis of monographs, articles, and special literature on the research problem, were used.

Empirical methods included an expert online survey used to determine the socio-economic and macroeconomic impact of the COVID-19 pandemic, various approaches to respond in different areas of the population's life, and measures, undertaken by various countries to support national economies in the context of the COVID-19 
pandemic. The expert online survey involved 40 experts, including employees of the city, and regional social services and health departments.

\section{Results}

Based on an expert survey, it was revealed that several indirect consequences were expected due to coronavirus infection (Table 1).

Table 1. Socio-economic impact of the COVID-19 pandemic

\begin{tabular}{|c|c|c|c|c|}
\hline No & $\begin{array}{l}\text { Impact of } \\
\text { the COVID-19 pandemic } \\
\text { on the socio-economic sphere }\end{array}$ & $\begin{array}{l}\text { The rationale of implications } \\
\text { of the COVID-19 pandemic impact }\end{array}$ & $\% *$ & Rank \\
\hline 1 & $\begin{array}{l}\text { Risk of rapid incidence rate } \\
\text { and significant complications } \\
\text { resulted from Kazakhstan's } \\
\text { demographic characteristics }\end{array}$ & $\begin{array}{l}\text { A significant proportion of older people in Kazakhstan }(13.2 \% \text { of the total } \\
\text { population) make the country vulnerable to coronavirus infection. Almost all } \\
\text { older people in Kazakhstan have at least one chronic disease that can lead to very } \\
\text { high mortality rates among groups of older people }\end{array}$ & $90 \%$ & 1 \\
\hline & $\begin{array}{l}\text { Violation of children's access to } \\
\text { educational services }\end{array}$ & $\begin{array}{l}\text { The government of Kazakhstan has decided to close all educational institutions } \\
\text { in the country. If this decision is continued, it will lead to disruption of the } \\
\text { educational process, gaps in child care, and economic consequences for working } \\
\text { parents. If schools are closed for a long time, this may affect the passing of state } \\
\text { exams and admission to higher education institutions }\end{array}$ & $85 \%$ & 2 \\
\hline 3 & $\begin{array}{l}\text { Deterioration of other medical } \\
\text { services }\end{array}$ & $\begin{array}{l}\text { Health facilities are expected to redirect existing resources and trained staff } \\
\text { to regions most affected by COVID-19 that may limit the availability of other } \\
\text { essential health services, such as access to HIV/tuberculosis treatment, safe } \\
\text { delivery and newborn care, access to dialysis systems, and other treatment for } \\
\text { chronic diseases that require constant monitoring in health facilities }\end{array}$ & $80 \%$ & 3 \\
\hline 4 & $\begin{array}{l}\text { Impact on mental health and } \\
\text { psychosocial well-being of the } \\
\text { population }\end{array}$ & $\begin{array}{l}\text { Fear of the incidence of coronavirus infection can lead to public disorder and } \\
\text { disruption of public order. Also, it may be difficult to access and obtain necessary } \\
\text { social services and psychosocial support, including protection of victims of } \\
\text { domestic violence, services rendered to the elderly, people with disabilities, and } \\
\text { other vulnerable groups }\end{array}$ & $75 \%$ & $4-5$ \\
\hline 5 & $\begin{array}{l}\text { Violation of access to markets } \\
\text { and basic goods }\end{array}$ & $\begin{array}{l}\text { Relative to market demand, the pandemic has significantly affected supply } \\
\text { chains around the world. As shown by the experience of many countries where } \\
\text { COVID-19 cases have been reported, panic-induced mass purchases and } \\
\text { inventory creation can be expected. Besides, logistics constraints are expected } \\
\text { to affect agricultural supply chains. Farmers are concerned about the reduced } \\
\text { demand for animal products and the eventual economic consequences for the } \\
\text { agricultural sector. Small farmers and self-employed producers, who own small } \\
\text { businesses that provide income for them in local markets, are more vulnerable to } \\
\text { a crisis }\end{array}$ & $75 \%$ & $4-5$ \\
\hline
\end{tabular}

Note: compiled based on an expert survey; ${ }^{*}-$ the percentage of expert mentions

According to $60 \%$ of the experts surveyed, in Kazakhstan, it is still difficult to assess the eventual damage, since it has not yet been clearly manifested, but the situation changes daily. However, according to one respondent, "the global economic impact of COVID-19, combined with a decrease in public confidence in state institutions, can create an additional burden on the country's economy. There are concerns that the restrictions already imposed will lead to significant losses for business and the budget, while additional funds may be needed to strengthen and ensure the readiness of the health system". In the preliminary analysis of the main current negative consequences of the coronavirus pandemic for the RK's economy, experts indicated the following (Table 2). 
Table 2. Macroeconomic impact of COVID-19 pandemic

\begin{tabular}{|c|c|c|c|}
\hline No & Macroeconomic impact of COVID-19 pandemic & $\% *$ & Rank \\
\hline 1 & The outflow of foreign direct investment, which will reduce economic growth and jobs & $90 \%$ & 1 \\
\hline 2 & Direct business losses, which will lead to lower tax revenue and reduction of income & $85 \%$ & $2-3$ \\
\hline 3 & $\begin{array}{l}\text { A decrease in the output of micro- and small enterprises operating in retail markets and in the service sector, } \\
\text { which are a means of subsistence for self-employed }\end{array}$ & $85 \%$ & $2-3$ \\
\hline 4 & Reduction of domestic demand and foreign trade, a decrease in revenues from imports and exports & $80 \%$ & 4 \\
\hline 5 & $\begin{array}{l}\text { The growth of inflationary expectations of the population, an increase in demand for foreign currency and, in the } \\
\text { future, the devaluation of the national currency, a decrease in gold and foreign exchange reserves }\end{array}$ & $75 \%$ & 5 \\
\hline
\end{tabular}

Note: compiled based on an expert survey; *-percentage of expert mentions

Experts ( $75 \%$ of respondents) believe that it is difficult to predict the further development of the situation with the spread of the COVID-19 pandemic, and the extent to which emergency quarantine measures imposed de facto by the government and institutions will slow down the incidence of the virus. The scope of the consequences of coronavirus infection, both direct and indirect, will depend largely on two factors. The first is the response rate of the public health system (including the risk warning communication component), and the second is the operational efficiency of controlling the spread of COVID-19.

\section{Discussion}

According to most experts ( $85 \%$ of respondents), the goal of responding to overcome COVID-19 is focusing on efforts to minimize the potential humanitarian consequences of the COVID-19 spread in Kazakhstan by the end of 2020.

Experts have proposed the following national response measures to prevent consequences for the health system (Table 3) and indirect influence on people's lives (Table 4).

Table 3. Response measures and activities related to health system implications (public health service cluster)

\begin{tabular}{|c|c|c|c|}
\hline No & Response measures and activities & $\% *$ & Rank \\
\hline 1 & $\begin{array}{l}\text { Providing legal and regulatory support for changes to relevant legislation to facilitate a timely response, in particular, } \\
\text { by training government executives on how to apply the updated mechanisms }\end{array}$ & $90 \%$ & 1 \\
\hline 2 & $\begin{array}{l}\text { Developing a national communication plan on emerging risks in emergencies to increase communication on health } \\
\text { service issues and conduct information campaigns addressed to various segments of society }\end{array}$ & $85 \%$ & $2-3$ \\
\hline 3 & $\begin{array}{l}\text { Improving the collection and assessment of information on cases involving health risks at the national and regional levels to actively } \\
\text { monitor such cases in the country }\end{array}$ & $85 \%$ & $2-3$ \\
\hline 4 & $\begin{array}{l}\text { Strengthening control measures at the country's entry points by introducing screening, developing response } \\
\text { capabilities in normal situations and emergencies, and conducting rapid tests, clinical case management mechanisms, } \\
\text { and referral to isolation }\end{array}$ & $80 \%$ & 4 \\
\hline 5 & $\begin{array}{l}\text { Developing laboratory capabilities at the national and regional levels for testing COVID-19 by providing equipment, } \\
\text { trained personnel, sets of reagents, implementing testing systems in regional and central laboratories, in particular, } \\
\text { making decisions on logistical issues of sampling-kits delivery }\end{array}$ & $75 \%$ & 5 \\
\hline 6 & $\begin{array}{l}\text { Strengthening measures to prevent and control infectious diseases, approving relevant regulations and implementing } \\
\text { them in medical facilities intended to treat COVID-19 patients, creating appropriate programs for reference medical } \\
\text { institutions, and providing the resources for their implementation (including training), ensuring proper collection } \\
\text { and disposal of infected waste }\end{array}$ & $75 \%$ & $5-6$ \\
\hline 7 & $\begin{array}{l}\text { Strengthening the investigation of cases of infected people and ensuring rapid response to them, including training } \\
\text { of rapid response teams at the regional level, training of specialists at primary health care institutions to track patient } \\
\text { contacts, providing personal protective gear and other necessary materials }\end{array}$ & $70 \%$ & 7 \\
\hline 8 & $\begin{array}{l}\text { Developing rapid delivery, procurement, and inventory management mechanisms for health emergencies, including } \\
\text { operational assessments of current inventory capabilities, delivery and distribution systems, and updating systems to } \\
\text { manage the supply of necessary materials and equipment (e.g. personal protective gear, test kits, laboratory supplies) }\end{array}$ & $65 \%$ & $8-9$ \\
\hline 9 & $\begin{array}{l}\text { Mapping the spread of the virus for strategic response planning, and conducting a series of assessments to determine } \\
\text { the complex impact of the COVID-19 pandemic on different population groups }\end{array}$ & $65 \%$ & $8-9$ \\
\hline
\end{tabular}


Table 4. Response measures and activities related to the indirect impact on people's lives

\begin{tabular}{|c|c|c|c|}
\hline No & Response measures and activities & $\% *$ & Rank \\
\hline \multicolumn{4}{|c|}{ Security cluster } \\
\hline 1 & $\begin{array}{l}\text { Strengthening social protection systems to support the most vulnerable population groups, providing } \\
\text { psychosocial support to vulnerable population groups, including training of psychosocial support advisers, } \\
\text { preventing domestic violence related to quarantine risks }\end{array}$ & $90 \%$ & 1 \\
\hline 2 & $\begin{array}{l}\text { Providing access to alternative care for vulnerable population groups such as children, who are deprived } \\
\text { of parental care due to the coronavirus infection (due to hospitalization or death of parents or guardians), } \\
\text { training foster parents or staff of family-type orphanages in care and psychosocial support in connection with } \\
\text { COVID-19, providing financial help, providing families affected by coronavirus infection with necessities }\end{array}$ & $85 \%$ & $2-3$ \\
\hline 3 & $\begin{array}{l}\text { Providing mental health and psychosocial support, as well as rehabilitation support for all groups of people } \\
\text { affected by coronavirus infection, including creating online mental health and psychosocial support tools, } \\
\text { recreational therapy materials, and rendering other services to provide psychosocial support }\end{array}$ & $85 \%$ & $2-3$ \\
\hline 4 & $\begin{array}{l}\text { Monitoring compliance with human rights during and after getting out of the quarantine, with special } \\
\text { attention to people who need help the most }\end{array}$ & $80 \%$ & 4 \\
\hline \multicolumn{4}{|c|}{ Water supply, sanitation, and hygiene cluster } \\
\hline 5 & $\begin{array}{l}\text { Expanding nation-wide campaigns to comply with hygiene requirements and ensuring hand-washing } \\
\text { facilities in social and public institutions }\end{array}$ & $85 \%$ & 1 \\
\hline 6 & $\begin{array}{l}\text { Developing and adopting a set of communication materials, including awareness-raising materials } \\
\text { comprising information about COVID-19, and meeting hygiene requirements to inform the population } \\
\text { about ways of transmitting coronavirus infection, identifying symptoms of the decease, and protecting } \\
\text { yourself and others, informing as where to address and what to do in the event of illness, as well as refuting } \\
\text { common fakes about the disease }\end{array}$ & $75 \%$ & 2 \\
\hline 7 & Ensuring water supply and disinfectants in social and public institutions & $70 \%$ & 3 \\
\hline \multicolumn{4}{|c|}{ Food and economic security, livelihoods } \\
\hline 8 & $\begin{array}{l}\text { Supporting local businesses and/or micro-, small and medium-sized enterprises with grants to reorganize } \\
\text { their activities, reduce job losses, create new employment opportunities, and minimize the negative impact } \\
\text { on the local economy }\end{array}$ & $80 \%$ & 1 \\
\hline 9 & $\begin{array}{l}\text { Providing the livelihoods to the most vulnerable households and increasing food production to prevent } \\
\text { eventual food security problems }\end{array}$ & $65 \%$ & 2 \\
\hline \multicolumn{4}{|c|}{$\begin{array}{ll} & \text { Education }\end{array}$} \\
\hline 10 & $\begin{array}{l}\text { Supporting public authorities to minimize long-term disruption of access to basic services, in particular, } \\
\text { access to education for children, through the implementation of online/distance learning }\end{array}$ & $65 \%$ & 1 \\
\hline \multicolumn{4}{|c|}{ Housing and nonfood goods sector } \\
\hline 11 & $\begin{array}{l}\text { Providing kits of essential nonfood goods (NFG), in particular, personal protective gear for the population. } \\
\text { Subject to effective organization, such events can be held together with information campaigns on } \\
\text { COVID-19 coronavirus infection, contribute to their effectiveness, and ensure the mental health of residents }\end{array}$ & $85 \%$ & 1 \\
\hline 12 & $\begin{array}{l}\text { Organizing temporary solutions for the accommodation of medical teams, mobile places for distribution of } \\
\text { NFG kits, COVID-19 rapid tests, etc. }\end{array}$ & $75 \%$ & 2 \\
\hline
\end{tabular}

Note: compiled based on an expert survey; ${ }^{*}$ - percentage of expert mentions

As an example, the experts presented measures to support the population, undertaken by the European governments, who went opposite ways in the fight against the spread of COVID-19. Thus, on the one hand, Austria and Switzerland have already taken steps to get out of quarantine, while, on the other hand, Sweden did not impose prohibitive measures at all.

Since the beginning of the restrictions, the Austrian Federal Government has decided on a package of assistance measures worth EUR 38 bln to prevent mass unemployment and bankruptcy of companies. EUR 4 bln were provided for subsidies to enterprises in connection with the transition to short working hours during the COVID-19 pandemic.

To prevent the mass bankruptcy of enterprises and support their solvency, the government has allocated EUR $9 \mathrm{bln}$ in the form of guarantees to secure loans received by enterprises. Guarantees are applied to loans that amount up to EUR $1.5 \mathrm{mln}$. The guarantee can cover up to $80 \%$ of the loan amount. A special procedure was applied to companies involved in the tourism industry. Small and medium-sized tourist enterprises can get a guarantee for $80 \%$ of the loan up to EUR 400 thous. for a period of up to 36 months through the Austrian Hotel 
and Tourism Bank. Another EUR 15 bln are expected to be spent on emergency assistance to support industries which might particularly suffer from ongoing COVID-19 pandemic (EURACTIV.com with Reuters, 2020).

To provide financial support to small family businesses, including businesses run by one person and individual entrepreneurs, the so-called Strength Fund was created amounting to EUR $1 \mathrm{bln}$. The mentioned enterprises have also received the opportunity to defer social contributions. Businesses are allowed to defer or spread tax payments, as well as get the full or partial write-off of penalties. In general, during the period of falling sales, imposed tax deferral amounts to EUR 10 bln (Sinn, 2020).

In Switzerland, strict quarantine measures were imposed on March 16, 2020. Following the declared extreme situation, any mass events were prohibited, and all public catering establishments, sports, and entertainment establishments were closed, as well as all stores, except for grocery stores and pharmacies.

To mitigate the economic consequences of the pandemic, the Swiss Federal Government allocated CHF $42 \mathrm{bln}$. The target funds were directed to support employment (remote work from home and transition to a reduced work schedule), pay wages, attract the self-employed, prevent bankruptcy, provide preferential loans, and support the culture and sports.

Due to the decrease in the solvency of companies, immediate assistance was provided for obtaining guaranteed loans in the amount of CHF $20 \mathrm{bln}$. Affected companies can easily get loans at $10 \%$ of sales (up to a maximum of CHF $20 \mathrm{mln}$ ). Amounts up to CHF 500,000 must be paid immediately under a 100\% guarantee from the federal government. Loans over CHF 500,000 are guaranteed by the federal government at $85 \%$ (Geiserm, \& Allen, 2020).

Companies suffered from the coronavirus pandemic are granted temporary interest-free deferred payments for social insurance contributions. Debt collection and payments through bankruptcy are also terminated.

Liquidity buffers are being created in the tax sphere. For the period from March 1 to December 31, 2020, a zero-interest rate on VAT, customs duties, and special consumption taxes have been introduced. This provision also applies to direct federal tax.

Measures to finance the tourism industry are undertaken as well. Thus, CHF $5.5 \mathrm{mln}$ are allocated to the Swiss Society for Hotel Credit, and CHF $530 \mathrm{mln}$ are provided for federal loans in the tourism industry (Charlton, 2020).

Practically no restrictions related to the spread of the coronavirus pandemic were undertaken in Sweden. After making several amendments to the country's budget, which provide for implementing measures to support the economic situation for over SEK $300 \mathrm{bln}$, the government has announced the need to revise the country's budget to provide additional allocations aimed at supporting small and medium-sized businesses, as the most vulnerable in the current conditions.

In general, as of today, the Swedish government has implemented the following measures (Ministry of Finance, 2020):

- The state took over the payment of sick leave in full during April and May (previously, the first day of sick leave was not paid, while the following two weeks were paid by the employer), as well as the main share of expenses for temporary layoffs due to COVID-19.

- Subsidies have been announced to companies to pay half of the employees' wages, provided that they receive $90 \%$ of the prepayment, and work $40 \%$ of the working day.

- Companies have been granted the right to defer social charges and individual taxes for the next 12 months. The Swedish Tax Service has allowed businesses that have paid taxes in advance for the first half of 2020 to return the specified amount.

- The National Bank of Sweden provides loans to enterprises through banks for SEK 500 bln (approximately USD 56 bln). 


\section{Conclusion}

The results of the study have confirmed the initially stated hypothesis that the use of economic tools to support the population and eliminate the consequences of applying emergency measures protecting the country's security can ease the socio-economic situation of the population and minimize the impact of restrictive measures on the country's economic development.

It should be noted that the world has long been dominated by the concept of absolute security, i.e. it was believed that it was possible to create a secure system of any complexity. Today it has become obvious that no absolutely safe system can be created, and only danger can be absolute. To make effective managerial decisions, quantitative information about the level of hazards and threats, as well as their dependence on various factors is necessary. To get such information, special tools are needed that would make it possible to create an appropriate decision support system for predicting and minimizing the consequences of natural and man-made emergencies.

Even though the security problem has been considered quite often in the scientific literature, today there are almost no studies dealing with the systematic analysis of the application of economic tools to support the population, and eliminate the consequences of the emergency measures taken to protect the country's security in cases of natural and anthropogenic threats. This problem may become an issue for further research.

\section{References}

Abdikerova, G., \& Omarova, A. 2016. The social consequences of natural and man-made emergency: The regional aspect. International Journal of Environmental and Science Education, 11(7), 1433-1442.

Aitkazina, M., Ermek, N., Syrlybekkyzy, S., Koibakova, S., Zhidebayeva, A., \& Aubakiro, M.Zh. 2019. Threats to Sustainable Development due to Increase of Greenhouse Gas Emissions in a Key Sector. Journal of Security and Sustainability Issues, 9, 227-240. https:// doi.org/10.9770/jssi.2019.9.1(17)

Akeel, H., Khoj, H. 2020. Is education or Real GDP per capita helped countries staying at home during COVID-19 pandemic: crosssection evidence? Entrepreneurship and sustainability Issues, 8(1), 841-852. http://doi.org/10.9770/jesi.2020.8.1(56)

Avin, S., Wintle, B.C., Weitzdörfer, J., Ó., Éigeartaigh, S.S., Sutherland, W.J., \& Rees, M.J. 2018. Classifying global catastrophic risks. Futures, 102, 20-26.

Axworthy, L. 2001. Human security and global governance: Putting people first. Global Insights, 7(1), 19-23.

Bambery, Z., Cassell, C.H., Bunnell, R.E., Kakoli R., Zara A., Payne R.L., \& Meltzer, M.I. 2018. Impact of a hypothetical infectious disease outbreak on US exports and export-based jobs. Health Security, 16(1), 1-7.

Baum, S. 2015. The far future argument for confronting catastrophic threats to humanity: Practical significance and alternatives. Futures, 72, 86-96.

Besenyő, J.; Kármán, M. 2020. Effects of COVID-19 pandemy on African health, political and economic strategy, Insights into Regional Development 2(3): 630-644. https://doi.org/10.9770/IRD.2020.2.3(2)

Bostrom, N. 2019. The vulnerable world hypothesis. Global Policy, 10(4), 455-476.

Bulkhairova, Zh.S., Saimagambetova, G.A., Kizimbayeva, A., Kadyrova, G.M., \& Abdiyeva, S.R. 2019. The Situationof Food Security in Kazakhstan. Space and Culture, 7(1). https://doi.org/10.20896/saci.v7i1.469

Burkaltseva, D.D., Blazheich, O.G., Gabrielyan, O.A., Savchenko, L.V., Skorobogatova, T.N., Guk, O.A., Abubakarov, M.A. 2019. Development of the financial security of the state: neutralization of threats. Revista Inclusiones, 6(Especial), $294-312$.

Cascio, J. 2019. The apocalypse: It's not the end of the world. Bulletin of Atomic Scientists, 75(6), 269-272.

Charlton, E. 2020. Switzerland fast-tracks emergency aid for small businesses weathering COVID-19. Retrieved from https://www. weforum.org/agenda/2020/04/switzerland-covid-19-coronavirus-small-business-loans-recession-economy/ 
Eakin, H., \& Luers, A.L. 2006. Assessing the vulnerability of social-environmental systems, The Annual Review of Environment and Resources, 31, 365-394.

EURACTIV.com with Reuters. 2020. Austria launches coronavirus aid, ready to help support companies. Retrieved from https://www. euractiv.com/section/coronavirus/news/austria-launches-coronavirus-aid-ready-to-help-support-companies/

Eurasian Economic Commission. 2020. Monitoring of measures taken by the EEU member states aimed at overcoming the negative consequences of the coronavirus infection (COVID-2019) spread. Retrieved from http://www.eurasiancommission.org/ru/Documents/ МОНИТОРИНГ\%20на\%2002.04.pdf

Geiserm U., \& Allen, M. 2020. Switzerland imposes sweeping measures to contain coronavirus. Retrieved from https://www.swissinfo. ch/eng/government-acts_switzerland-imposes-sweeping-measures-to-contain-coronavirus/45615344

Golubev, S.S., Sekerin, V.D., Gorokhova, A.E., \& Bank, S.V. 2020. Problems of Economic Security in the Arctic Region. Journal of Environmental Management and Tourism, 10(7), 1495-1508. https://doi.org/10.14505//jemt.v10.7(39).07

Katanaeva, M.A., Grozovsky, G.I., Lartseva, T.A., Vyacheslavova, O.F., \& Parfenyeva, I.E. 2020. Risk-Oriented Thinking in the Quality Management System of an Organization. Revista Inclusiones, 7(1), 311-317. Retrieved from http://www.archivosrevistainclusiones. com/gallery/19\%20vol\%207\%20num\%201\%20enemar2020ncl.pdf

Kulikov, I.M., \& Minakov, I.A. 2019. Food security: Problems and prospects in Russia, Scientific Papers Series Management, Economic Engineering in Agriculture and Rural Development, 19(4), 141-147. Retrieved from http://managementjournal.usamv.ro/pdf/vol.19_4/ volume_19_4_2019.pdf

Kurmasheva, A. 2020. Business against coronavirus: How entrepreneurs in Kazakhstan help in the harsh period. Retrieved from https:// liter.kz/biznes-protiv-koronavirusa-kak-v-kaza

Lipinsky, D.A., Makareiko, N.V., Musatkina, A.A. 2019. Legal Aspects of Ensuring Economic Security in The Conditions of the Digital Economy Development. Amazonia Investiga, 8(20), 568- 574.

Melnikov, A.B., Mikhailushkin, P.V., Poltarykhin, A.L., Dibrova, Z.N. 2019. Economic aspects of the resolution of the issue of food security: a case study. Entrepreneurship and Sustainability Issues, 7(1), 595-602. https://doi.org/10.9770/jesi.2019.7.1(41)

Ministry of Finance. 2020. Economic measures in response to COVID-19. Government Offices of Sweden. Retrieved from https://www. government.se/articles/2020/03/economic-measures-in-response-to-covid-19/

Myers, S.S., \& Patz, J.A. 2009. Emerging threats to human health from global environmental change. The Annual Review of Environment and Resources, 34, 223-252.

OECD. 2011. OECD Reviews of Risk Management Policies. Future Global Shocks. Retrieved from https://www.oecd.org/governance/48256382.pdf

OECD. 2020. OECD Economic Outlook. Coronavirus: the world economy at risk. Retrieved from https://www.oecd.org/economicoutlook/

Oliński, M., Szamrowski, P. 2020. Is education or Real GDP per capita helped countries staying at home during COVID-19 pandemic: cross-section evidence? Entrepreneurship and sustainability Issues, 8(1), 853-867. http://doi.org/10.9770/jesi.2020.8.1(57)

Plèta, T., Tvaronavičienė, M., Casa, S. D., Agafonov, K. 2020. Cyber-attacks to critical energy infrastructure and management issues: overview of selected cases. Insights into Regional Development, 2(3), 703-715. https://doi.org/10.9770/IRD.2020.2.3(7)

Razif, M., Miraja, B.A., Persada, S.F., Nadlifatin, R., Belgiawan, P.F., Redi, A.A.N.P., Lin, S-Ch. 2020. Investigating the role of environmental concern and the unified theory of acceptance and use of technology on working from home technologies adoption during COVID-19. Entrepreneurship and Sustainability Issues, 8(1), 795-808. http://doi.org/10.9770/jesi.2020.8.1(53)

Sinn, H.-W. 2020. How best to fight the economic impact of the coronavirus pandemic. Retrieved from https://www.theguardian.com/ business/2020/mar/17/how-best-to-fight-the-economic-impact-of-the-coronavirus-pandemic

Smith, K.R., \& Ezzati, M. 2005. How environmental health risks change with development: The epidemiologic and environmental risk transitions revisited. The Annual Review of Environment and Resources, 30, 291-333.

Thomalla, F., Downing, T., Spanger-Siegfried, E., Han, G., \& Rockström, J. 2006. Reducing human vulnerability to climate-related hazards: Towards a common approach between climate change adaptation and disaster risk reduction communities. Disasters, 30(1), 39-48.

Tokhayeva, Z.O., Almukhambetova, B.Z., Keneshbayev, B., \& Akhmetova, K. 2020. Innovative processes' management in agriculture and food security: development opportunities. Entrepreneurship and Sustainability Issues, 7(3), 1565-1579. https://oi.org/10.9770/ 
JOURNAL OF SECURITY AND SUSTAINABILITY ISSUES

ISSN 2029-7017 print/ISSN 2029-7025 online

jesi.2020.7.3(10)

Western, J. 2016. What is global in global security studies? Journal of Global Security Studies, 1(1), 99-101.

Yuesti, A., Rustiarini, N.W., Suryandari, N.N.A. 2020. Financial literacy in the COVID-19 pandemic: pressure conditions in Indonesia. Entrepreneurship and sustainability Issues, 8(1), 884-898. http://doi.org/10.9770/jesi.2020.8.1(59)

\section{Gulnar Shaimardanovna KALIAKPAROVA}

ORCID 0000-0002-1859-9774

Yelena Evgenevna GRIDNEVA

ORCID 0000-0002-3279-2036

\section{Sara Sarsebekovna ASSANOVA}

ORCID 0000-0002-7077-1367

Kulyash Shaymoldenovna SYZDYKOVA

ORCID 0000-0001-5228-1842

Sandugash Babagalikyzy SAURANBAY

ORCID 0000-0001-7567-6900

This work is licensed under the Creative Commons Attribution International License (CC BY) http://creativecommons.org/licenses/by/4.0/ 